\section{5. 牛耳下腺の酸性ホスファターゼについて}

$$
\text { (九困大・生化学) 大 田 康 男 }
$$

口腔領域の立場から，唾液腺の器官特異性及び，その 意義の検討と，酵素の蛋白化学的研究を意図して，唾液 腺からの酵素を研究してきた。

今回は比較的取り扱い易い酸性 monophosphoesterase について，若干の検討を加えた。

基質として，P-Nitrophenyl phosphate を用い，0.2 M の Acetate Buffer (又はO.1M Citrate Buffer) で PH5. 2 (又はPH5.0) として反応させて，遊離してくる P-Nitrophenol 0.5M - Carbonate Buffer (PH9.6) でアルカリ性として発色せしめ，O. $\mathrm{D}_{42} \mathrm{~m} \mu$ の吸光度か ら，酵素活性を定量した。

その結果,

1. PH4.5〜6.0の間に少なくと屯 3つの isozyme の 存在を認めた。 その至適PHは夫々 4.5, 5.0, 5.6 (0.05 M・Citrate Buffer) であった.

2. O.1M Acetate Buffer ではその至適 PH はやや アルカリ側にずれ, Citrate Bufferよりあ10〜20\%高い 活性を示した。

3. DE A E Column Chromato. Fraction で最も 高い Specific Act を示した Enzyme (至適PH5.0) に ১いて,

(1) $\mathrm{Km}=1.3 \times 10^{-4} \mathrm{M}$

(口) $\mathbf{M g}++$ は必ずしあ Activator とはならず，10-2 M 以上ではかえってその酵素活性を阻害する。

( Citrate Buffer 中では, NaF, Tartarate による 阻害は見られなかった。

6. 牛耳下腺よりのN-アセチルヘキンサミンー6一燐 酸デアセチラーゼの精製と2，3の性質について (九都大·生化学) 於 勢 雅

牛耳下腺エキスを用いて，Nーアセチルグルコサミン ー6一燐酸を脱アセチルし，その終産物として，グルコ サミンー6ー燐酸と酢酸を生ずることを初めてしめした のは松下及び高木（1966年）である。

本研究に於ては同じ材料を用いて，この脱アセチル反 応を触媒する酳素を簡便な分離法乙数段階の処理によっ て純化する方法を報告する．又Nーアセチルマンノサミ ンキナーゼの調製に関する新しく開発した一方法を併せ て報告する。

純化された脱アセチル酵素は $\mathrm{DEAE}$ セルローズカラ ムの溶出パターンに於て単一のピークを示し, 又濾紙電 気泳動に於ても単一のスポットを示したので単一の蛋白
から成るものと推定された。

本酵素は通常の緩衝系を用いた反応混液に於て $\mathrm{PH} 8$ 〜 9 間の広い至適 $\mathrm{PH}$ を有し，特別の共同因子の添 加を必要としない.

基質特異性に関する研究の結果, 本酵素は $\mathrm{N}$ ーアセチ

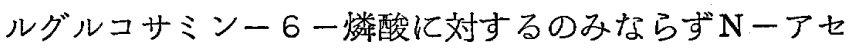
チルマンノサミンー6ー燐酸に対してあ殆んど等しい速 度で脱アセチルを行い，更に，効率は悪いがNーアセチ ルガラクトサミンー6一燐酸をむ脱アセチルした．その Kmは前者は9. $3 \times 10^{-4} \mathrm{M}$ であり後者は1. $42 \times 10^{-3} \mathrm{M}$ であ った.

本酵素の活性は価陽イオン, 特に $\mathrm{Hg}^{2+}, \mathrm{Cu}^{2+}$ 及び $\mathrm{Cd}^{2+}$ によって強く阻害され，それより作用は劣るが $\mathrm{Sn}^{2+}$ 及 び $\mathrm{Zn}^{2}+$ によっても阻害された. 又, Parachloromercuribenzoate は強い阻害を示した. 従って, 酵素蛋白 の遊離の SH 基が本酵素の活性に関係していると思われ る. 本酵素は還元剂特にグルタチオン, システイン及び 亜硫酸ソーダ等の添加によって部分的な活性化及び安定 化を受けることが示された.

本酵素の生体内分布亡しては耳下腺の他に顎下腺，気 管支軟骨, 腸管, 肺, 膵臓, 腎臓, 朋臓等に可成豊富に 分布するが或る種の下等脊椎動物に於ては極めて乏しい ことが示された.

\section{Candida 属の Tween80 加培地上における一発 育現象（第 2 報）}

$$
\text { (九歯大・細菌) ○北村吉緒・秋貞泰輔 }
$$

緒言 : Candida 属の中 C.alb., C.trop. および C. stellat. が SCLT, aDT 雨培地上で発育集落の周团に白 輪を形成することを知り，これが菌種鑑別の一助となる ことを前回の本学会で報告した. 今回は Gomori の硫化 鉛法による菌体内脂肪分解酵素の検出を行ない，培地中 の Tween20,40,60，80 の Tween 類ならびに油脂類 についても検討し，また Glucose の量によって白輪の 形成が抑制されることを認めたので報告する。

方法：培地はSCLT, aDT 両培地の 2 種類を使用し， 油脂類については Lard oil, Olive oil を Tween の代 りに添加したものを用いた。菌株はC.alb., C.trop., C. stellat., C. guillierm. および C. kr.の5秼を用い た. 培養方法は前回同様, 培地にリングで円形の凹陥部 を作り, サブロー agar 48時間培養した供試菌株の菌液 を】滴，滴下し $25^{\circ} \mathrm{C}$ 培養した。 また glucose の白輪 形成におよぼす影響を test するため glucose の量を SCLT 培地にO. 3，0.4，0.5，0.6\%を加え，aDT 培地 